\title{
Development of New Energy Vehicles at Home and Abroad
}

\author{
Yishan $\mathrm{Xu}$ \\ School of economics and management \\ North China Electric Power University \\ Beijing, China
}

\begin{abstract}
With the rapid development of the economy and the intensification of environmental pollution, in the present situation, the development of new energy vehicles is the trend of the times. In recent years, China has made great achievements in the new energy auto industry, but there is still a big gap compared with the international advanced level. In addition, there are still a lot of problems in the promotion of new energy vehicles in our country. Based on reading related literature and field research, this paper compares the development of new energy vehicle policy and technology at home and abroad, and puts forward countermeasures and suggestions for the development of new energy vehicles in China.
\end{abstract}

Keywords-new energy vehicle; policy and technology; international comparison; development suggestions

\section{INTRODUCTION}

With the development of economy and the rapid growth of population, the world energy and environmental problems are becoming increasingly serious. In addition, due to the development of science and technology, innovation has become a new economic growth point; countries have increased efforts to promote the transformation of traditional economy. In this case, countries are aware of energy saving and emission reduction is the future direction of the development of the automotive industry. New energy automotive industry has become one of the industries actively developing in various countries.

\section{DEFINITION AND CLASSIFICATION OF NEW ENERGY VEHICLES}

At the end of nineteenth Century, with the development of the second scientific and technological revolution, electric vehicles entered people's life. However, due to the limitations of mileage, with the development of oil mining and automotive technology, fuel vehicles gradually replaced the electric vehicle. In the 1970s, many oil crises made Western countries begin to realize the necessity of developing new energy vehicles. Since 1990s, many countries and regions have introduced a series of law and policies to promote the development of new energy vehicles. The outbreak of the world economic crisis in 2008 brought heavy blows to the economy of various countries. After the economic crisis, countries have strengthened the support for the new energy automotive industry, and promoted the automobile technology reform and industrial upgrading, in order to enhance the competitiveness of the domestic automobile industry.
New energy vehicles refers to the use of non-conventional vehicle fuel as a power source (or the use of conventional fuels, the new vehicle power device), advanced technology, power control and drive the vehicle, the formation of advanced technology principle, new technology, new structure of automobile. At present, the new energy vehicles can be divided into the following categories:

\section{A. Pure electric vehicles}

Pure electric vehicles are vehicles that rely solely on batteries for power. The battery drives the car's internal drive by providing power to drive the car to run.

Pure electric vehicles have little pollution, low noise, and reduce dependence on traditional fuels. Compared with the traditional vehicle, it is simple in structure and easy to operate. However, because of its power mainly from the battery, its mileage is shorter and the battery technology requirements are higher.

\section{B. Fuel cell vehicles}

The working principle of fuel cell electric vehicle is that hydrogen and air in the fuel cell generate energy by chemical reaction under the action of catalyst, driving the operation of vehicle. Unlike pure electric vehicles, fuel cells can generate electricity directly.

The energy conversion rate of fuel cell is high. Because its main fuel is hydrogen, the pollution is very small. However, hydrogen is not easy to extract and the cost is higher, which has become an important factor restricting its development.

\section{Hybrid electric vehicle}

Hybrid electric vehicles refer to the combination of electric drive and internal combustion engine drive. According to the power division, it can be divided into oil and electric hybrid vehicles (including gasoline hybrid vehicles and diesel hybrid vehicles), compressed air hybrid vehicles and multi fuel hybrid vehicles. And according to the classification of working methods, it can be divided into series hybrid electric vehicles, parallel hybrid vehicles and hybrid electric vehicles.

Hybrid electric vehicles can give full play to the dual advantages of internal combustion engines and fuel vehicles. Because of the combination of electric power and internal combustion engine, its driving range is longer. Compared with traditional cars, it has lower fuel consumption and relatively 
clean exhaust gas. Therefore, it is the most market-oriented and industrialized prospects of the car.

\section{COMPARISON OF NEW ENERGY VEHICLES POLICY AND TECHNOLOGY AT HOME AND ABROAD}

\section{A. Comparison of new energy vehicle policies at home and abroad}

\section{1) New energy vehicle policy in foreign countries}

New energy automotive industry as a new industry, its R \& $\mathrm{D}$, production and promotion need the strong support of government policy. It is the two direction of government policy to increase support to new energy automobile company and increase market demand.

a) Increasing support for new energy automotive companies. In order to promote the development of new energy vehicles, the state has given a large amount of financial support to new energy automobile companies. In June 12, 2008, the US Department of Energy announced that it would allocate $\$ 30$ million to the plug-in hybrid electric vehicle research project by general motors, Ford motor and Ge Corp in 2008 2011. In July 2016, the United States government issued the first electric vehicle industry development package in the name of the White House, including 4 billion 500 million US government loan guarantee, and 10 million US dollars per year to promote the battery 500 project.

b) Developing demand market. Western countries have developed preferential policies to improve infrastructure construction and consumers' enthusiasm for new energy vehicles. Taking Japan as an example, car purchase subsidy and infrastructure construction have been the two key directions in the development of new energy vehicles in Japan. In the "EV PHV road map", Japan proposed in the national highway, provincial road and highway service areas and other places to set enough charging piles, to meet the people's charging demand.[1]

\section{2) Domestic new energy vehicle policy}

In 2001, China launched the major projects of electric vehicles in the 863 Program. YISHION electric vehicles, hybrid vehicles and fuel cell vehicles for "three vertical", the multi energy powertrain control system, drive motor and power battery technology for the three kinds of "three horizontal", our country has established the "three vertical and three horizontal" development layout, to create a good beginning for the development of new energy Automotive Industry.

The year 2009 can be regarded as another milestone in the development of new energy automotive industry in China. In this year, the state and local issued a series of industrial policies, further increased the support for the new energy automobile industry, the use of new energy vehicles began to gradually spread. In January 23, 2009, the Ministry of Finance and the Ministry of science and Technology issued a "notice" regarding the development of energy-saving and new energy vehicle demonstration pilot work, to carry out energy-saving and new energy vehicle demonstration pilot work in Beijing, Shanghai, Chongqing, Dalian, Hangzhou, Changchun, Ji'nan, Wuhan, Shenzhen, Hefei, Changsha, Kunming and Nanchang city, to promote the use of units to buy energy-saving and new energy vehicles subsidies. In April 2009, Chinese government decided to provide 60 thousand Yuan subsidy to consumers who bought pure electric vehicles, and invested in automobile battery charging stations in some cities. In 2009, Beijing city announced that it will add 500 million Yuan to start the "green" bus fleet plan. The implementation of these policies provided strong policy support for the development of new energy automotive industry. China's new energy automotive industry once again developed rapidly.[2]

In December 2016, China issued a notice on adjusting the subsidy policy for the popularization and application of new energy vehicles, which decided to adjust and improve the subsidy policy of popularization and application, and to implement the responsibility of the main application and promotion, and to establish a punishment mechanism. [3] The introduction of this policy, adjusted the subsidy standards for new energy vehicles. In addition to fuel cell vehicles, all types of vehicles2019-2020 in central and local subsidy standards and limit, in the basis of existing standards fall $20 \%$, which makes the new energy vehicle market competition is more intense, require enterprises to reduce their own cost. At the same time, the establishment of a punishment mechanism, also further regulate the new energy vehicle market in China, to ensure the sustainable and healthy development of new energy automotive industry.

\section{B. Comparison of new energy vehicle technology at home and abroad}

\section{1) New energy vehicle technology abroad}

Advanced technology is the key to the development of new energy vehicles. Since the rapid development of new energy vehicles, Japan, the United States, Europe and other developed countries and regions attach great importance to the technological innovation of new energy vehicles. They spend lots of money on technology research and development every year, hoping to take the lead and gain competitive advantage.

In terms of fuel cell technology, the United States and Japan are at the forefront of the world. According to the data released by China Patent Information Center, from the number of patents in the world, Japan has the largest number of patents related to the battery and its management system of pure electric vehicles, followed by the United States. [4] In 1996, Toyota Corporation developed a prototype of fuel cell vehicles, and began the mass production of hybrid vehicles in 1997, becoming the earliest practitioner of new energy vehicles. In 2009, Japan established the development of high performance electric vehicle power battery industry alliance; jointly implement "leather new battery cutting-edge science basic research special", to overcome the key technology of battery. In 2009, the U.S. government also set up R \& D centers in Kentucky to develop high-performance lithium batteries. Other countries have also made great achievements in this field. Canada's proton exchange membrane fuel cell technology is the world leader. [5] Germany's first driverless electric bus is also trying to run.

In addition to battery technology, countries are actively developing other energy as a new vehicle power, solar energy 
vehicles, natural gas vehicles, alcohol fuel vehicles have made some achievements. [6]

\section{2) Domestic new energy vehicle technology}

Since the implementation of the 863 plan, under the strong support of the national government, the development of China's new energy automotive industry has made significant progress, China's new energy vehicle technology is also maturing.

In recent years, China's pure electric vehicle research and development capabilities increased significantly, some of the technology has reached the international advanced level. Fuel cell technology in our country has been a major breakthrough, lithium battery technology and NiMH battery has reached world advanced level. In addition, China's automotive motor products technology has made great progress. China's auto enterprises also rely on their own technology, occupying a place in the global market. Byd Co entered the automobile manufacturing industry in 2003. The enterprise occupies an important position in the global new energy automobile market with its strong innovation ability and unique technology. BYD has the independent intellectual property rights of the iron battery, to achieve high capacity, high safety and low cost breakthrough. BYD F3DM becomes the world's first dual mode electric vehicle for mass production. [5]

While we are proud of our important achievements, we should also understand that there is still a big gap between China and the developed countries in terms of new energy vehicle technology. We should continue to promote technological research and development, promote the development of new energy automotive industry, and gain competitive advantage.

\section{SUGGESTIONS ON THE DEVELOPMENT OF NEW ENERGY VEHICLES IN CHINA}

Recently, we investigated the views and usage of new energy vehicles through questionnaires and field surveys. Here are the results of our survey:

For the promotion of new energy vehicles, $73 \%$ of people expressed support, $1.27 \%$ of people opposed, $25.73 \%$ of people said that it does not matter. In contrast, in the survey of the crowd, only $5.49 \%$ of people said that the use of new energy vehicles. So we have investigated the factors that affect the use of new energy vehicles. We found that inconvenient charging and having private cars were the two major factors hindering people from using new energy vehicles.

From the above findings, we draw the conclusion: Although the country is vigorously promoting new energy vehicles, the market is still a "political hot market cold" situation. Although most people agree with the promotion of new energy vehicles, the number of people who use it is still not very much.

According to our findings, we propose the following suggestions for the development of new energy vehicles in China:

a) The state should continue to strengthen the support of new energy vehicles. On the one hand, we should increase the support for new energy automobile enterprises, formulate relevant laws and regulations, standardize the new energy automobile market, and provide a good external environment for the development of new energy vehicles. On the other hand, preferential policies should be adopted to increase the subsidies to consumers, encourage green consumption, and expand the market for new energy vehicles. The government's support should focus on the whole industry chain and establish a longterm mechanism for the development of new energy vehicles.

b) Speeding up the research and development of new energy vehicle technology. The state should increase investment in science and technology enterprises, strengthen the protection of intellectual property rights, encourage enterprises for independent innovation, improve production capacity, to ensure the safety of new energy vehicles, to provide various types of new energy automotive products, to better meet the diverse needs of consumers, to gain competitive advantage.

c) Strengthen the construction of supporting facilities. Due to the Limited mileage of new energy vehicles, charging is difficult to become a major problem in the promotion of new energy vehicles. To speed up the construction of public charging facilities, unified charging facilities standards, enhance the safety, versatility and openness of the facilities, to meet consumer demand for electricity, improve consumer convenience, and promote the widespread use of new energy vehicles.

d) Providing more comprehensive services. For the public, new energy vehicles are still a new thing, so consumers may encounter a lot of problems need to be solved in the process of using. Good comprehensive service can increase customer satisfaction, enhance the enthusiasm of consumers to buy new energy vehicles, and also helps to shape the corporate image.

\section{SUMMARY}

The development and promotion of new energy vehicles is of great significance to solve the problems of energy shortage and environmental pollution. New energy vehicle is the inevitable trend of future automotive industry development. China should seize this opportunity, increase support for new energy vehicles, learn advanced foreign technology, learn from experience, focus on scientific research, dare to innovate, accelerate the transformation of China's auto industry, so that China's auto industry into the global leading ranks.

\section{REFERENCES}

[1] Wenjin Wu, Research on development path and policy of new energy vehicles in China under low carbon economy [M].Beijing: Economic Science Press, 2014.10:29-59 (In Chinese)

[2] Liuqin Chen, Development and policy support of new energy automotive industry in China [J]. Automotive Engineer, 2010,(07):12-15 (In Chinese)

[3] Ministry of industry and information technology of the People's Republic of China. http://www.miit.gov.cn/

[4] National competition for electric vehicle battery technology patent http://www.cnpat.com.cn/show/news/NewsInfo.aspx?Type=Z\&NewsId $=2767$

[5] Baojun Tang, New energy vehicles: path and Policy Research [M].Beijing: Science Press,2015.1:18-72(In Chinese) 
[6] Zhenguo Zhang, Development status and trends of new energy vehicles at home and abroad [C]. Energy saving and emission reduction and New
Energy Vehicle Technology Forum .Wuhan: Hubei Association for science and technology, 2009:10-14 (In Chinese) 